\title{
МЕХАНИЗМ ОБЕСПЕЧЕНИЯ НАЦИОНАЛЬНЫХ ИНТЕРЕСОВ
}

\author{
Бидова Бэла Бертовна \\ кандидат юридических наук, доцент, \\ заведующий кафедрой уголовного права и криминологии \\ Чеченский государственный университет
}

\begin{abstract}
Аннотация: в статье проведен анализ результативности жизнедеятельности системы (а точнее, механизма) обеспечения национальных интересов; в этом же ракурсе рассмотрена оптимизация данного механизма. Автором сделан вывод о том, что оптимизация есть как раз инструмент повышения результативности механизма обеспечения национальных интересов.
\end{abstract}

Ключевые слова: национальные интересы, механизм обеспечения, оптимизация, результативность права.

\section{Bidova Bela Bertovna}

Abstract: the article analyzes the effectiveness of the system (or rather, the mechanism) of ensuring national interests; the optimization of this mechanism is considered in the same perspective. The author concludes that optimization is just a tool for improving the effectiveness of the mechanism for ensuring national interests.

Key words: national interests, security mechanism, optimization, effectiveness of law.

В справочной литературе термин «инструмент (средство)» воспринимается как методы, приемы, операции, осуществляемые для реализации каких-либо, стоящих перед кем-то, целей; как то, что деятельность для свершения той или иной цели, требуется для реализации, достижения чего-то (нас интересует именно достижение результативности) $[1$, c.239].

Анализируемое нами понятие «оптимизация» происходит от слова «оптимальный», что переводится как наиболее «подходящий», «приемлемый». Оба эти понятия производные от латинского слова «optimus», то есть лучший.

Относительно данного вопроса В.П. Беляев и С.Ю. Чапчиков придерживаются следующего мнения: «Как правило, оптимизация в общепринятом понимании означает обнаружение самой лучшей (из числа 
вероятных) версий достижения цели при условии, что известны требования и предел возможностей» [2, с.11]. Например, оптимизация управления - это «процесс, заключающийся в нахождении способа разрешения управленческих задач при самых лучших (как правило, наименьших или наибольших) параметрах, описывающих такой процесс, в частности, за наименьший временной интервал, с максимальной экономической эффективностью, с предельной четкостью» [3, с.51]. В этом случае оптимизация рассматривается также как определенный процесс. Вот почему понятие «результативность права» в правоведении всегда уподобляется безукоризненности, разумности (рациональности), оптимальности, аргументированности [4, с.43].

Например, С.M. Пелевиным в 70-е годы XX века была высказана следующая точка зрения: «результативность правовых норм выражается в соразмерности инструментов правового регулирования и методов использования права с теми социальными отношениями, на стабилизации которых они сосредоточены, сообразности цели, соответствующей объективистским условиям совершенствования социума» [5, с.98]. Исследователь делает акцент на взаимовлиянии инструментов и целей в установлении результативности правовых норм.

Следует признать, что базис доктрины результативности права в российском правоведении был сформулирован еще в научных трудах таких исследователей, как В.В. Глазырин, В.И. Никитинский, И.С. Самощенко. Они расценивали результативность права как уровень соответствия целей, поставленных законодателем перед собой, результатам, полученным в процессе фактического правоприменения [6, с.119].

Современные исследователи также уделяют внимание интересующей нас проблематике. Например, согласно Л.А. Морозовой, результативность правового упорядочивания подразумевает под собой «степень соответствия результата правового упорядочивания возлагающейся на него задачи» [7, с.319]. Ученый заостряет внимание именно на соотношении поставленных задач и полученных результатов, в чем, без сомнения, есть резон.

Сходную позицию в этом вопросе занимают также А.С. Пиголкин и Ю.А. Дмитриев [8, с.481], изложившие ее в совместной научной работе.

Равным образом, Г.Н. Манов полагает, что результативность правового регулирования «сопряжена с конституированием целей принятия той или иной правовой нормы, эффектом от ее применения, соотношением полученных результатов, цели и неминуемых издержек. Абсолютная результативность правовой нормы возможна при достижении всех ее целей - как текущих, так и 
перспективных и итоговых - с нанесением наименьшего вреда для социума, минимальными материальными расходами, в кратчайшие сроки» [9, с.213]. Здесь делается акцент на достижение целей правовой нормы.

В результате рассмотрения точек зрения относительно проблемы результативности норм права (правового регулирования, правоприменительных документов и пр.) возникает убежденность в несостоятельности предположения, что результативность права можно ограничить проблемой соразмерности целей, установленных на законодательном уровне, фактически полученным результатам.

Следует выделять новую методику (подход) оценки результативности существующих сейчас законов. Данный подход выражается в следующих характеристиках правового явления:

а) место и роль правового явления в правовой структуре социума;

б) анализ функций правового явления в правовой структуре;

г) последствия реализации правового явления во взаимодействии с другими правовыми явлениями, входящими в состав правовой структуры;

д) правовая структура (правовое регулирование, нормотворчество).

Осмелимся предложить обособить следующие признаки всеобъемлющего оценивания результативности права:

- соотношение целей нормы права и фактически полученных результатов (эффективность);

- соответствие правовой нормы общественным ценностям и интересам общества.

Таким образом, результативность механизма обеспечения национальных интересов определяется условиями, имеющими отношение к фиксирующим его нормам права (их добротности, структурности, соответствию социальным отношениям и вообще качеству нормотворчества).

\section{Список литературы}

1. Ожегов С.И. Толковый словарь русского языка: около 100000 слов, терминов и фразеологических выражений. М.: Издательство АСТ, 2020. $1360 \mathrm{c}$.

2. Беляев В.П., Чапчиков С.Ю. Оптимизация как средство повышения эффективности механизма обеспечения национальной безопасности: понятие и взаимообусловленность // Известия юго-западного государственного университета. Серия: история и право. 2018.2 (27). С. 7-13. 
3. Любитенко Д.Ю. Оптимизация правовой политики в Российской Федерации и роль Конституционного Суда РФ // Вестник Калининградского юридического института МВД России. 2010. № 4. С. 51-52.

4. Явич Л.С. Эффективность действия правовой системы // Советское государство и право. 1970. № 3. С. 41-44.

5. Пелевин С.М. Эффективность права и законодательства о разводах // Правоведение. 1971. № 3. С. 96-104.

6. Эффективность правовых норм / Глазырин В.В., Кудрявцев В.Н., Никитинский В.И., Самощенко И.С. М.: Юрид. лит., 1980. - 280 с.

7. Морозова Л.А. Теория государства и права: учебник. М.: Эксмо, 2010. $510 \mathrm{c}$.

8. Теория государства и права: учебник / под ред. А.С. Пиголкина, Ю.А. Дмитриева. М.: Юрайт, 2019. 516 с.

(C) Б.Б. Бидова, 2020 